\title{
IMA Commission on New Minerals, Nomenclature and Classification (CNMNC) - Newsletter 60
}

\author{
Ritsuro Miyawaki ${ }^{1}$, Frédéric Hatert ${ }^{2}$, Marco Pasero ${ }^{3}$, and Stuart J. Mills ${ }^{4}$ \\ ${ }^{1}$ Chairman, CNMNC I Department of Geology, National Museum of Nature and Science, \\ 4-1-1 Amakubo, Tsukuba 305-0005, Japan \\ ${ }^{2}$ Vice-Chairman, CNMNC I Laboratoire de Minéralogie, Université de Liège, \\ Bâtiment B18, Sart Tilman, 4000 Liège, Belgium \\ ${ }^{3}$ Vice-Chairman, CNMNC I Dipartimento di Scienze della Terra, Università di Pisa, \\ Via Santa Maria 53, 56126 Pisa, Italy \\ ${ }^{4}$ Secretary, CNMNC I Geosciences, Museum Victoria, P.O. Box 666, Melbourne, Victoria 3001, Australia
}

Correspondence: Marco Pasero (marco.pasero@unipi.it)

Received: 24 March 2021 - Published: 22 April 2021

The information given here is provided by the IMA Commission on New Minerals, Nomenclature and Classification for comparative purposes and as a service to mineralogists working on new species.

Each mineral is described in the following format:

- mineral name, if the authors agree on its release prior to the full description appearing in press;

- chemical formula;

- type locality;

- full authorship of proposal;

- e-mail address of corresponding author;

- relationship to other minerals;

- crystal system, space group, structure determined, yes or no;

- unit-cell parameters;

- strongest lines in the X-ray powder diffraction pattern;

- type specimen repository and specimen number;

- citation details for the mineral prior to publication of full description.

Citation details concern the fact that this information will be published in the European Journal of Mineralogy on a routine basis, as well as being added month by month to the commission's website.
It is still a requirement for the authors to publish a full description of the new mineral.

No other information will be released by the commission.

\section{New mineral proposals approved in February 2021}

IMA no. 2019-033a

Haitaite-(La)

$\mathrm{LaU}^{4+} \mathrm{Fe}_{2}^{3+}\left(\mathrm{Ti}_{13} \mathrm{Fe}_{4}^{2+} \mathrm{Fe}^{3+}\right)_{\Sigma 18} \mathrm{O}_{38}$

Haita town, Miyi County, Sichuan province, China $\left(26^{\circ} 54^{\prime} 13^{\prime \prime} \mathrm{N}, 102^{\circ} 01^{\prime} 27^{\prime \prime} \mathrm{E}\right)$

Fenggang Wang*, Guang Fan, Ting Li, Xiangkun Ge, Yu Wu, Huan Wang, and Jian Yao

*E-mail: wfg9818@163.com

Crichtonite group

Trigonal: $R \overline{3}$; structure determined

$a=10.3678(5), c=20.839(1) \AA$

$3.391(79), 3.241(65), 3.039(49), 2.994(46), 2.871(100)$, 2.475(62), 1.694(58), 1.436(55)

Type material is deposited in the mineralogical collections of the Geological Museum of China, No. 16 Yangrou Hutong, Xisi, Beijing 100031, People's Republic of China, catalogue number M13859

How to cite: Wang, F., Fan, G., Li, T., Ge, X., Wu, Y., Wang, H., and Yao, J.: Haitaite-(La), IMA 2019033a, in: CNMNC Newsletter 60, Eur. J. Mineral., 33, https://doi.org/10.5194/ejm-33-203-2021, 2021. 
IMA no. 2020-081

Dobšináite

$\mathrm{Ca}_{2} \mathrm{Ca}\left(\mathrm{AsO}_{4}\right)_{2} \cdot 2 \mathrm{H}_{2} \mathrm{O}$

Dionýz mining field, Zemberg-Terézia vein system, $2.2 \mathrm{~km}$ NE of the Dobšiná town, Spišsko-gemerské rudohorie Mts., Rožňava Co., Košice Region, Slovakia $\left(48^{\circ} 50^{\prime} 17^{\prime \prime} \mathrm{N}\right.$, $\left.20^{\circ} 23^{\prime} 01^{\prime \prime} \mathrm{E}\right)$

Jiří Sejkora*, Martin Števko, Radek Škoda, Eva Vúšková, Jiří Toman, Sebastián Hreus, Jakub Plášil, and Zdeněk Dolníček *E-mail: jiri.sejkora@nm.cz

Roselite group

Monoclinic: $P 2{ }_{1} / c$

$a=5.990(2), \quad b=13.013(4), \quad c=5.726(2) \AA, \quad \beta=$ $108.47(3)^{\circ}$

5.197(37), 5.002(33), 3.443(38), 3.385(66), 3.249(77), 3.201(42), 3.026(100), 2.822(60)

Type material is deposited in the mineralogical collections of the Moravian Museum, Department of Mineralogy and Petrology, Zelný trh 6, Brno, Czech Republic, catalogue number B12257

How to cite: Sejkora, J., Števko, M., Škoda, R., Víšková, E., Toman, J., Hreus, S., Plášil, J., and Dolníček, Z.: Dobšináite, IMA 2020-081, in: CNMNC Newsletter 60, Eur. J. Mineral., 33, https://doi.org/10.5194/ejm-33-203-2021, 2021.

\section{IMA no. 2020-082}

Bobfinchite

$\mathrm{Na}\left[\left(\mathrm{UO}_{2}\right)_{8} \mathrm{O}_{3}(\mathrm{OH})_{11}\right] \cdot 10 \mathrm{H}_{2} \mathrm{O}$

Burro mine, Slick Rock district, San Miguel Co., Colorado, USA ( $\left.38^{\circ} 02^{\prime} 42^{\prime \prime} \mathrm{N}, 108^{\circ} 53^{\prime} 23^{\prime \prime} \mathrm{W}\right)$

Travis A. Olds*, Jakub Plášil, Anthony R. Kampf, Peter Burns, Joe Marty, and John S. McCloy

*E-mail: oldst@carnegiemnh.org

Schoepite family

Orthorhombic: $P b c n$; structure determined

$a=14.6249(9), b=14.0389(10), c=16.6923(10) \AA$

$7.337(100), 3.658(21), 3.590(50), 3.516(22), 3.229(63)$,

3.176(36), 2.568(20), 2.013(23)

Type material is deposited in the mineralogical collections of the Natural History Museum of Los Angeles County, 900 Exposition Boulevard, Los Angeles, CA 90007, USA, catalogue number 75146

How to cite: Olds, T. A., Plášil, J., Kampf, A. R., Burns, P., Marty, J., and McCloy, J. S.: Bobfinchite, IMA 2020082, in: CNMNC Newsletter 60, Eur. J. Mineral., 33, https://doi.org/10.5194/ejm-33-203-2021, 2021.
IMA no. 2020-084

Yuzuxiangite

$\mathrm{Sr}_{3} \mathrm{Fe}^{3+}\left(\mathrm{Si}_{2} \mathrm{O}_{6}\right)_{2}(\mathrm{OH}) \cdot 3 \mathrm{H}_{2} \mathrm{O}$

Wessels mine, Kalahari Manganese Fields, Northern Cape Province, South Africa $\left(27^{\circ} 06^{\prime} 51.82^{\prime \prime} \mathrm{S}, 22^{\circ} 51^{\prime} 18.31^{\prime \prime} \mathrm{E}\right)$

Xiangping $\mathrm{Gu}^{*}$, Hexiong Yang, and Xiande Xie

*E-mail: guxp2004@163.com

The $\mathrm{Fe}^{3+}$ analogue of ohmilite

Monoclinic: $P 2{ }_{1} / \mathrm{m}$; structure determined

$a=11.1035(10), \quad b=7.8463(7), \quad c=7.8222(7) \AA, \quad \beta=$ $101.406(8)^{\circ}$

4.632(92), 3.486(100), 3.291(67), 3.175(38), 3.065(57), 2.841(48), 2.118(49), 1.956(46)

Type material is deposited in the mineralogical collections of the Geological Museum of China, No. 16 Yangrou Hutong, Xisi, Beijing 100031, People's Republic of China, catalogue number M16110 (holotype), the University of Arizona Mineral Museum, 1601 E University Blvd, Tucson, AZ 85719, USA, catalogue number 22692, and the RRUFF Project, deposition number R200008

How to cite: Gu, X., Yang, H., and Xie, X.: Yuzuxiangite, IMA 2020-084, in: CNMNC Newsletter 60, Eur. J. Mineral., 33, https://doi.org/10.5194/ejm-33-203-2021, 2021.

\section{IMA no. 2020-085}

Ferri-hellandite-(Ce)

$\left(\mathrm{Ca}_{3} \mathrm{Ce}\right) \mathrm{Ce}_{2} \mathrm{Fe}_{2}^{3+} \mathrm{B}_{4} \mathrm{Si}_{4} \mathrm{O}_{22}(\mathrm{OH})_{2}$

Sagåsen larvikite quarry, Mørje, Porsgrunn, Vestfold and Telemark, Norway $\left(59^{\circ} 02^{\prime} 39^{\prime \prime} \mathrm{N}, 9^{\circ} 49^{\prime} 46^{\prime \prime} \mathrm{E}\right)$

Henrik Friis*, Radek Škoda, Alf Olav Larsen, Michaela Vašinová-Galiová, Radim Čtvrtlík, and Jan Filip

*E-mail: henrik.friis@nhm.uio.no

Hellandite group

Monoclinic: $P 2 / a$; structure determined

$a=19.1616(2), \quad b=4.7561(4), \quad c=10.34016(1) \AA, \quad \beta=$ $111.173(1)^{\circ}$

8.934(37), 3.466(37), 3.246(33), 3.101(34), 2.929(37), 2.861(44), 2.658(100), 1.910(44)

Type material is deposited in the mineralogical collections of the Natural History Museum, University of Oslo, P.O. Box 1172, Blindern, 0318 Oslo, Norway, catalogue number KNR 44259 (XRD), and the Moravian Museum, Department of Mineralogy and Petrology, Zelný trh 6, Brno, Czech Republic, catalogue number B12258 (EMPA)

How to cite: Friis, H., Škoda, R., Larsen, A. O., VašinováGaliová, M., Čtvrtlík, R., and Filip, J.: Ferri-hellandite-(Ce), IMA 2020-085, in: CNMNC Newsletter 60, Eur. J. Mineral., 33, https://doi.org/10.5194/ejm-33-203-2021, 2021. 
IMA no. 2020-086

Elgoresyite

$\left(\mathrm{Mg}_{5} \mathrm{Si}_{2}\right) \mathrm{O}_{9}$

Suizhou meteorite (Suizhou L6 chondrite), Xihe, Zengdu District, Suizhou, Hubei, China $\left(31^{\circ} 37^{\prime}\right.$ N, $\left.113^{\circ} 28^{\prime} \mathrm{E}\right)$

Luca Bindi*, Ryosuke Sinmyo, Elena Bykova, Sergey V. Ovsyannikov, Catherine McCammon, Ilya Kupenko, Leyla Ismailova, Leonid Dubrovinsky, and Xiande Xie

*E-mail: luca.bindi@unifi.it

New structure type

Monoclinic: $C 2 / m$; structure determined

$a=9.397(2), \quad b=2.763(1), \quad c=11.088(3) \AA, \quad \beta=$ $94.25(2)^{\circ}$

$2.801(100), 2.563(35), 2.460(70), 2.308(40), 2.070(35)$, 2.017(55), 1.968(65), 1.845(60)

Type material is deposited in the mineralogical collections of the Museo di Storia Naturale, Università di Firenze, Via La Pira 4, I-50121, Florence, Italy, catalogue number 3238/I

How to cite: Bindi, L., Sinmyo, R., Bykova, E., Ovsyannikov, S. V., McCammon, C., Kupenko, I., Ismailova, L., Dubrovinsky, L., and Xie, X.: Elgoresyite, IMA 2020086, in: CNMNC Newsletter 60, Eur. J. Mineral., 33, https://doi.org/10.5194/ejm-33-203-2021, 2021.

\section{IMA no. 2020-087}

Phosphocyclite-(Fe)

$$
\mathrm{Fe}_{2}^{2+}\left(\mathrm{P}_{4} \mathrm{O}_{12}\right)
$$

Halamish Wadi, Hatrurim basin, Negev Desert, Israel $\left(31^{\circ} 09^{\prime} 47^{\prime \prime} \mathrm{N}, 35^{\circ} 17^{\prime} 57^{\prime \prime} \mathrm{E}\right)$

Sergey N. Britvin*, Mikhail N. Murashko, Yevgeny Vapnik, Natalia S. Vlasenko, Maria G. Krzhizhanovskaya, Oleg S. Vereshchagin, Vladimir N. Bocharov, and Maksim S. Lozhkin

*E-mail: sbritvin@gmail.com

The $\mathrm{Fe}^{2+}$ analogue of phosphocyclite-(Ni) (IMA no. 2020088; this newsletter)

Monoclinic: $C 2 / c$; structure determined

$a=11.834(4), \quad b=8.340(2), \quad c=9.911(2) \AA, \quad \beta=$ $118.50(4)^{\circ}$

$6.170(51), \quad 4.253(40), \quad 3.554(20), \quad 3.388(26), 3.201(30)$, 3.012(100), 2.600(23), 2.398(21)

Type material is deposited in the collections of the Fersman Mineralogical Museum, Russian Academy of Sciences, Leninskiy Prospekt 18-2, Moscow 119071, Russia, registration number 5596/1

How to cite: Britvin, S. N., Murashko, M. N., Vapnik, Y., Vlasenko, N. S., Krzhizhanovskaya, M. G., Vereshchagin, O. S., Bocharov, V. N., and Lozhkin, M. S.: Phosphocyclite(Fe), IMA 2020-087, in: CNMNC Newsletter 60, Eur. J. Mineral., 33, https://doi.org/10.5194/ejm-33-203-2021, 2021.

\section{IMA no. 2020-088}

Phosphocyclite-(Ni)

$\mathrm{Ni}_{2}\left(\mathrm{P}_{4} \mathrm{O}_{12}\right)$

Halamish Wadi, Hatrurim basin, Negev Desert, Israel $\left(31^{\circ} 09^{\prime} 47^{\prime \prime} \mathrm{N}, 35^{\circ} 17^{\prime} 57^{\prime \prime} \mathrm{E}\right)$

Sergey N. Britvin*, Mikhail N. Murashko, Yevgeny Vapnik, Natalia S. Vlasenko, Maria G. Krzhizhanovskaya, Oleg S. Vereshchagin, Vladimir N. Bocharov, and Maksim S. Lozhkin

*E-mail: sbritvin@gmail.com

The Ni analogue of phosphocyclite-(Fe) (IMA no. 2020-087; this newsletter)

Monoclinic: $C 2 / c$

$a=11.611(2), \quad b=8.218(2), \quad c=9.826(2) \AA, \quad \beta=$ $118.41(4)^{\circ}$

6.086(56), 4.211(39), 3.334(25), 3.145(29), 2.978(100), 2.833(26), 2.357(23), 2.081(23)

Type material is deposited in the collections of the Fersman Mineralogical Museum, Russian Academy of Sciences, Leninskiy Prospekt 18-2, Moscow 119071, Russia, registration number 5596/1

How to cite: Britvin, S. N., Murashko, M. N., Vapnik, Y., Vlasenko, N. S., Krzhizhanovskaya, M. G., Vereshchagin, O. S., Bocharov, V. N., and Lozhkin, M. S.: Phosphocyclite(Ni), IMA 2020-088, in: CNMNC Newsletter 60, Eur. J. Mineral., 33, https://doi.org/10.5194/ejm-33-203-2021, 2021.

\section{New mineral proposals approved in March 2021}

\section{IMA no. 2020-089}

Sluzhenikinite

$\mathrm{Pd}_{15}\left(\mathrm{Sb}_{7-x} \mathrm{Sn}_{x}\right) 3 \leq x \leq 4$

Oktyabrsk deposit (shaft no. 1, Oktyabrsk mine), Noril'sk deposits, Russia $\left(69^{\circ} 30^{\prime} 20^{\prime \prime} \mathrm{N}, 88^{\circ} 27^{\prime} 17^{\prime \prime} \mathrm{E}\right)$

Anna Vymazalová*, Mark D. Welch, František Laufek, Vladimir V. Kozlov, Chris J. Stanley, and Jakub Plášil

*E-mail: anna.vymazalova@geology.cz

New structure type

Monoclinic: $P 2{ }_{1} / m$; structure determined

$a=7.5558(1), \quad b=29.2967(3), \quad c=7.5713(1) \AA$, $\beta=119.931(2)^{\circ}$

$2.317(65), 2.315(100), 2.308(29), 2.187(89), 2.185(22)$, 2.183(74), 2.178(15), 2.177(25)

Type material is deposited in the collections of the Department of Earth Sciences, Natural History Museum, London SW7 5BD, UK, catalogue number BM 2020,20 (holotype), and the Fersman Mineralogical Museum, Russian Academy of Sciences, Leninskiy Prospekt 18-2, Moscow 119071, Russia, registration number 5691/1 (cotype) 
How to cite: Vymazalová, A., Welch, M. D., Laufek, F., Kozlov, V. V., Stanley, C. J., and Plášil, J.: Sluzhenikinite, IMA 2020-089, in: CNMNC Newsletter 60, Eur. J. Mineral., 33, https://doi.org/10.5194/ejm-33-203-2021, 2021.

\section{IMA no. 2020-090}

Protocaseyite

$\left[\mathrm{Al}_{4}(\mathrm{OH})_{6}\left(\mathrm{H}_{2} \mathrm{O}\right)_{12}\right]\left[\mathrm{V}_{10} \mathrm{O}_{28}\right] \cdot 8 \mathrm{H}_{2} \mathrm{O}$

Burro mine, Slick Rock district, San Miguel Co., Colorado, USA $\left(38^{\circ} 02^{\prime} 42^{\prime \prime} \mathrm{N}, 108^{\circ} 53^{\prime} 23^{\prime \prime} \mathrm{W}\right)$

Anthony R. Kampf*, Mark A. Cooper, John M. Hughes, Chi Ma, William H. Casey, and Joe Marty

*E-mail: akampf@nhm.org

Decavanadate family

Triclinic: $P \overline{1}$; structure determined

$a=9.435(2), \quad b=10.742(3), \quad c=11.205(3) \AA$, $\alpha=75.395(7), \beta=71.057(10), \gamma=81.286(6)^{\circ}$

10.38(100), $\quad 8.89(37), \quad 8.15(13), \quad 7.24(38), \quad 5.922(17)$, 2.177(11), 2.083(13), 1.785(11)

Cotype material is deposited in the mineralogical collections of the Natural History Museum of Los Angeles County, 900 Exposition Boulevard, Los Angeles, CA 90007, USA, catalogue numbers 75191, 75192 and 75193

How to cite: Kampf, A. R., Cooper, M. A., Hughes, J. M., Ma, C., Casey, W. H., and Marty, J.: Protocaseyite, IMA 2020-090, in: CNMNC Newsletter 60, Eur. J. Mineral., 33, https://doi.org/10.5194/ejm-33-203-2021, 2021.

\section{IMA no. 2020-091}

Shagamite

$\mathrm{KFe}_{11} \mathrm{O}_{17}$

Hatrurim Complex, Negev Desert, near Arad, Israel $\left(31^{\circ} 14^{\prime} 22^{\prime \prime} \mathrm{N}, 35^{\circ} 16^{\prime} 55^{\prime \prime} \mathrm{E}\right)$

Evgeny V. Galuskin*, Hannes Krüger, Irina O. Galuskina, Biljana Krüger, Krzysztof Nejbert, and Yevgeny Vapnik

*E-mail: evgeny.galuskin@us.edu.pl

The $\mathrm{Fe}^{3+}$ analogue of kahlenbergite

Hexagonal: $P 6_{3} / m m c$; structure determined

$a=5.9327(5), c=23.782(3) \AA$

11.89(100), 5.945(29), 2.834(61), 2.654(39), 2.554(25), 2.444(23), 2.375(22), 1.483(29)

Type material is deposited in the collections of the Fersman Mineralogical Museum, Russian Academy of Sciences, Leninskiy Prospekt 18-2, Moscow 119071, Russia, registration number 5634/1

How to cite: Galuskin, E. V., Krüger, H., Galuskina, I. O., Krüger, B., Nejbert, K., and Vapnik, Y.: Shagamite, IMA 2020-091, in: CNMNC Newsletter 60, Eur. J. Mineral., 33, https://doi.org/10.5194/ejm-33-203-2021, 2021.
IMA no. 2020-092

Moabite

$\mathrm{NiFe}^{3+}\left(\mathrm{PO}_{4}\right) \mathrm{O}$

Daba-Siwaqa pyrometamorphic complex, Transjordan Plateau, Jordan $\left(31^{\circ} 21^{\prime} 52^{\prime \prime} \mathrm{N}, 36^{\circ} 10^{\prime} 55^{\prime \prime} \mathrm{E}\right)$

Sergey N. Britvin*, Mikhail N. Murashko, Maria G. Krzhizhanovskaya, Yevgeny Vapnik, Natalia S. Vlasenko, Oleg S. Vereshchagin, Dmitrii V. Pankin, and Evgeny A. Vasiliev

*E-mail: sbritvin@gmail.com

New structure type

Orthorhombic: Pnma; structure determined

$a=7.216(2), b=6.406(1), c=7.471(2) \AA$

5.20(63), 3.321(37), 3.251(83), 2.726(100), 2.395(19),

2.354(25), 2.304(24), 2.049(18)

Type material is deposited in the collections of the Fersman Mineralogical Museum, Russian Academy of Sciences, Leninskiy Prospekt 18-2, Moscow 119071, Russia, registration number 5627/1

How to cite: Britvin, S. N., Murashko, M. N., Krzhizhanovskaya, M. G., Vapnik, Y., Vlasenko, N. S., Vereshchagin, O. S., Pankin, D. V., and Vasiliev, E. A.: Moabite, IMA 2020-092, in: CNMNC Newsletter 60, Eur. J. Mineral., 33, https://doi.org/10.5194/ejm-33-203-2021, 2021.

IMA no. 2020-093

Graulichite-(La)

$\mathrm{LaFe}_{3}^{3+}\left(\mathrm{AsO}_{4}\right)_{2}(\mathrm{OH})_{6}$

Patte d'Oie mine, Bou Skour mining district, Djebel Saghro mountain range, ca. $50 \mathrm{~km}$ south-east of Ouarzazate, Mo$\operatorname{rocco}\left(30^{\circ} 55^{\prime} 47^{\prime \prime} \mathrm{N}, 6^{\circ} 18^{\prime} 05^{\prime \prime} \mathrm{W}\right)$

Cristian Biagioni, Marco E. Ciriotti, Georges Favreau, Daniela Mauro, and Federica Zaccarini

*E-mail: cristian.biagioni@unipi.it

Alunite supergroup

Trigonal: $R \overline{3} m$; structure determined

$a=7.252(13), c=16.77(3) \AA$

$5.86(\mathrm{~m}), \quad 3.045(\mathrm{~s}), \quad 2.511(\mathrm{mw}), \quad 2.239(\mathrm{~m}), \quad 1.960(\mathrm{mw})$, $1.813(\mathrm{mw}), 1.689(\mathrm{mw}), 1.478(\mathrm{~m})$

Type material is deposited in the mineralogical collections of the Museo di Storia Naturale, Università di Pisa, Via Roma 79, Calci (PI), Italy, catalogue number 19924

How to cite: Biagioni, C., Ciriotti, M. E., Favreau, G., Mauro, D., and Zaccarini, F.: Graulichite-(La), IMA 2020093, in: CNMNC Newsletter 60, Eur. J. Mineral., 33, https://doi.org/10.5194/ejm-33-203-2021, 2021. 
IMA no. 2020-094

Yakubovichite

$\mathrm{CaNi}_{2} \mathrm{Fe}^{3+}\left(\mathrm{PO}_{4}\right)_{3}$

Daba-Siwaqa pyrometamorphic complex, Transjordan Plateau, Jordan $\left(31^{\circ} 21^{\prime} 52^{\prime \prime} \mathrm{N}, 36^{\circ} 10^{\prime} 55^{\prime \prime} \mathrm{E}\right)$

Sergey N. Britvin*, Mikhail N. Murashko, Maria G. Krzhizhanovskaya, Yevgeny Vapnik, Natalia S. Vlasenko, Oleg S. Vereshchagin, Dmitrii V. Pankin, and Anatoly A. Zolotarev

*E-mail: sbritvin@gmail.com

New structure type

Orthorhombic: Imma; structure determined

$a=10.388(1), b=13.088(1), c=6.4794(6) \AA$

5.82(44), 5.51(73), 5.21(32), 4.214(34), 3.013(31), 2.772(97), 2.748(100), 2.599(38)

Type material is deposited in the collections of the Fersman Mineralogical Museum, Russian Academy of Sciences, Leninskiy Prospekt 18-2, Moscow 119071, Russia, registration number 5626/1

How to cite: Britvin, S. N., Murashko, M. N., Krzhizhanovskaya, M. G., Vapnik, Y., Vlasenko, N. S., Vereshchagin, O. S., Pankin, D. V., and Zolotarev, A. A.: Yakubovichite, IMA 2020-094, in: CNMNC Newsletter 60, Eur. J. Mineral., 33, https://doi.org/10.5194/ejm-33-2032021, 2021.

IMA no. 2020-096

Tennantite- $(\mathrm{Cu})$

$\mathrm{Cu}_{6}\left(\mathrm{Cu}_{4} \mathrm{Cu}_{2}\right) \mathrm{As}_{4} \mathrm{~S}_{13}$

Layo epithermal deposit, Castilla Province, Arequipa Department, Peru $\left(15^{\circ} 11^{\prime} 16^{\prime \prime} \mathrm{S}, 72^{\circ} 14^{\prime} 30^{\prime \prime} \mathrm{W}\right)$

Cristian Biagioni*, Jiří Sejkora, Yves Moëlo, Eric Marcoux, Daniela Mauro, and Zdeněk Dolníček

*E-mail: cristian.biagioni@unipi.it

Tetrahedrite group

Cubic: $I \overline{4} 3 m$; structure determined

$a=10.171(1) \AA$

$4.152(4), \quad 2.936(100), \quad 2.543(18), \quad 1.995(4), \quad 1.857(8)$, 1.798(43), 1.650(4), 1.533(21)

Type material is deposited in the collections of the Department of Mineralogy and Petrology, National Museum in Prague, Cirkusová 1740, 19300 Prague 9, Czech Republic, catalogue number P1P 74/2020, the Museo di Storia Naturale, Università di Pisa, Via Roma 79, Calci (PI), catalogue number 19925, and the Mineralogical Museum (MINES ParisTech) of École des Mines de Paris, 60 Blvd. Saint-Michel, 75006 Paris, France, catalogue number ENSMP 83990

How to cite: Biagioni, C., Sejkora, J., Moëlo, Y., Marcoux, E., Mauro, D., and Dolníček, Z.: Tennantite-(Cu), IMA
2020-096, in: CNMNC Newsletter 60, Eur. J. Mineral., 33, https://doi.org/10.5194/ejm-33-203-2021, 2021.

\section{Nomenclature/classification proposals approved in February 2021}

\section{Nordite supergroup}

The nordite supergroup has been established. It currently includes six mineral species: nordite-(La), nordite-(Ce), ferronordite-(La), ferronordite-(Ce), manganonordite-(Ce), and meieranite. All but the latter species belong to the nordite group within the nordite supergroup. Meieranite is an unassigned member of the nordite supergroup.

\section{Nomenclature/classification proposals approved in March 2021}

\section{IMA 20-G: redefinition of philipsburgite}

Proposal 20-G is accepted. Philipsburgite shows an ordered distribution of As and $\mathrm{P}$ over two symmetrically independent tetrahedral sites and, therefore, is redefined with the new crystal-chemical formula $\mathrm{Cu}_{5} \mathrm{Zn}\left(\mathrm{AsO}_{4}\right)\left(\mathrm{PO}_{4}\right)(\mathrm{OH})_{6} \cdot \mathrm{H}_{2} \mathrm{O}$.

\section{IMA 20-H: redefinition of lazurite}

Proposal 20- $\mathrm{H}$ is accepted, and lazurite is redefined with the idealized formula $\mathrm{Na}_{7} \mathrm{Ca}\left(\mathrm{Al}_{6} \mathrm{Si}_{6} \mathrm{O}_{24}\right)\left(\mathrm{SO}_{4}\right)\left(\mathrm{S}_{3}\right)^{-} \cdot \mathrm{H}_{2} \mathrm{O}$. The neotype specimen originates from the Malo-Bystrinskoe gem lazurite deposit, Baikal Lake area, eastern Siberia, Russia. It is deposited in the collection of the Sidorov Mineralogical Museum (INRTU), Lermontova St. 83, Irkutsk 664074, Russia, registration number MMU/MF 27914.

\section{IMA 20-I: redefinition of aldermanite}

Proposal 20-I is accepted, and the formula of aldermanite is revised to account for essential $\mathrm{Na}$ in the structure and for minor $\mathrm{F}$ substitution for $\mathrm{OH}$. The simplified formula becomes $\left[\mathrm{Mg}\left(\mathrm{H}_{2} \mathrm{O}\right)_{6}\right]\left[\mathrm{Na}\left(\mathrm{H}_{2} \mathrm{O}\right)_{2} \mathrm{Al}_{3}\left(\mathrm{PO}_{4}\right)_{2}(\mathrm{OH}, \mathrm{F})_{6}\right] \cdot \mathrm{H}_{2} \mathrm{O}$, corresponding to the ideal end-member formula $\left[\mathrm{Mg}\left(\mathrm{H}_{2} \mathrm{O}\right)_{6}\right]\left[\mathrm{Na}\left(\mathrm{H}_{2} \mathrm{O}\right)_{2} \mathrm{Al}_{3}\left(\mathrm{PO}_{4}\right)_{2}(\mathrm{OH})_{6}\right] \cdot \mathrm{H}_{2} \mathrm{O}$.

\section{Revised chemical formulae}

\subsection{Sakhaite and harkerite}

In the IMA List of Minerals the formula for sakhaite is given as $\mathrm{Ca}_{48} \mathrm{Mg}_{16} \mathrm{Al}\left(\mathrm{SiO}_{3} \mathrm{OH}\right)_{4}\left(\mathrm{CO}_{3}\right)_{16}\left(\mathrm{BO}_{3}\right)_{28} \cdot\left(\mathrm{H}_{2} \mathrm{O}\right)_{3}(\mathrm{HCl})_{3}$. This formula is mirrored from the 2008 Nickel-Nichols list, is not charge-balanced, and has an obscure origin. Actually in the original description of holotype sakhaite (Zap. Vses. 
Miner. Obsh., 95, 193-202, 1966; Am. Mineral., 51, 1815$1820,1966)$, as well as in a subsequent crystal structure study (Dokl. Akad. Nauk SSSR, 239, 1103-1106, 1978), the mineral is given as Al-Si-free.

Sakhaite is closely related to harkerite. A recent detailed study of the sakhaite-harkerite solid solution, based on 14 single-crystal structure refinements (Am. Mineral., 103, 1749-1760, 2018), shows that the two minerals are related by the substitution of four $\left(\mathrm{BO}_{3}\right)$ triangles by a pentamer formed by one $\left(\mathrm{AlO}_{4}\right)+$ four $\left(\mathrm{SiO}_{4}\right)$ tetrahedra (with one oxygen atom protonated).

The two end-member compositions can be taken as the ideal formulae for harkerite and sakhaite, as follows:

harkerite:

$\mathrm{Ca}_{48} \mathrm{Mg}_{16}\left[\mathrm{AlSi}_{4} \mathrm{O}_{15}(\mathrm{OH})\right]_{4}\left(\mathrm{BO}_{3}\right)_{16}\left(\mathrm{CO}_{3}\right)_{16} \cdot 2\left(\mathrm{H}_{2} \mathrm{O}, \mathrm{HCl}\right)$

sakhaite:

$\mathrm{Ca}_{48} \mathrm{Mg}_{16}\left(\mathrm{BO}_{3}\right)_{32}\left(\mathrm{CO}_{3}\right)_{16} \cdot 2\left(\mathrm{H}_{2} \mathrm{O}, \mathrm{HCl}\right)$

The formulae of harkerite and sakhaite have been modified in the IMA List of Minerals accordingly.

\subsection{Tiettaite}

A paper on the mineral tiettaite has been published recently (Crystallogr. Rep., 66, 76-85, 2021) in which the ideal chemical formula of the mineral is given as $\mathrm{K}_{4} \mathrm{Na}_{12} \mathrm{Fe}_{2}^{3+} \mathrm{Si}_{16} \mathrm{O}_{41}(\mathrm{OH})_{4} \cdot 2 \mathrm{H}_{2} \mathrm{O}$, based on a combined Rietveld and EPMA study carried out on a sample of tiettaite after a new finding from the type locality. With respect to the previously accepted formula, potassium is an essential constituent, and titanium is not an essential constituent anymore. The crystal structure of tiettaite has been refined for the first time and shows that there are two sites occupied by $\mathrm{K}$ and four sites occupied by Na. Moreover there is a single octahedral site which is occupied mainly by $\mathrm{Fe}^{3+}$, with very minor Ti. Also in holotype tiettaite it is invariably $\mathrm{Fe}^{3+}>\mathrm{Ti}$. These data were examined carefully by the CNMNC officers and were considered reliable. Accordingly it was agreed to modify the formula of tiettaite in the official IMA List of Minerals. 